\title{
THE EFFECT OF ELDERLY ACADEMIC AND ACUPRESSURE IN THE DECREASE OF HYPERTENSION IN POSYANDU LANSIA SRONDOL BANYUMANIK SEMARANG
}

\author{
Nurhayati $^{\mathrm{a}^{*}}$, Aisyah Nur Azizah ${ }^{\mathrm{b}}$, Amirul Kadafic $^{\mathrm{c}}$ Mardiyono $^{\mathrm{d}}$ \\ ${ }^{a}$ Poltekkes Kemenkes Banjarmasin ; Mistar Cokrokusumo ; \\ Banjarmasin 70714 ; Indonesia \\ b,c,d Poltekkes Kemenkes Semarang ; Tirto Agung Pedalangan ; \\ Semarang 50268 ; Indonesia
}

\begin{abstract}
Elderly Gymnastics, Acupressure, Hypertension, Elderly. Hypertension is the number one occurrence that causes death. Hypertension is a lifelong disease and treatment can be done using blood and using long-term anti hypertensive agents. The purpose of this study was to determine whether patients could make improvements in hypertensive patients at the Posyandu Srondol Banyumanik elderly. This type of research is quasi experimental design with a sample of 22 respondents, 11 respondents received treatment for elderly gymnastics while 11 respondents received acupressure treatment. The study was conducted once a week for 3 weeks with 60 minutes of elderly gymnastics and 10 minutes of acupressure. The results of this study prove that there were no significant differences in blood pressure before and after treatment. This is evidenced by the value of $\rho>0.05$. In addition from the results of the mean mean difference between acupressure and elderly gymnastics, it can be seen that acupressure is more effective in lowering blood pressure compared to elderly gymnastics. Conclusion: acupressure is more effective in lowering blood pressure than elderly exercise.
\end{abstract}

Keywords: elderly gymnastics ; acupressure ; hypertension ; elderly

\section{Introduction}

The current lifestyle that is completely instant and lack of exercise will cause many diseases in the body, one of which is hypertension. Hypertension can increase the risk of disease, stroke, ischemic heart disease, heart failure, kidney disease and premature infant mortality (Liu X, 2017). Hypertension is a type of non-communicable disease (PTM) that kills 36 million people (WHO 2010). According to the American Heart Association (AHA), the American population suffering from hypertension reaches 74.5 million. In Indonesia, the prevalence of hypertension decreased from 31.7 percent in 2007 to 25.8 percent in 2013. According to data from the Central Java

*) Corresponding Author (Nurhayati)

E-mail: lucyavarisha10@gmail.com
Provincial Health Office, the incidence of hypertension in 2015 reached 57.87\% (Profil Kesehatan, 2015).

Hypertension cannot be cured, it can only be controlled with medication or lifestyle control. One way to control hypertension with a lifestyle is to exercise or exercise. To control high blood pressure in patients can do physical activity or elderly exercise. This exercise is an easy activity to do, has dynamic movements and causes a sense of excitement, so that it can reduce blood pressure. This is in accordance with I Gusti Agung's 2013 study on Elderly Gymnastics Reducing High Blood Pressure carried out 3 times a week for 6 weeks get the average systolic pressure results before treatment $144.63 \mathrm{mmHg}$ to $136.88 \mathrm{mmHg}$ (Mayuni, 2013).

Management of hypertension can also be 
done in the traditional way (Yankestrad). Yankestrad consists of 4 types, namely herb yankestrad (health services that use herbal medicine, aromatherapy, gurah, homeopathy and spa), skills with tools (acupuncture, chiropraction, cupping/cupping, apiterapi, ceragem, and acupressure), skills without tools (massage) massage, special massage for mother /baby, treatment of broken bones, and reflection), and skills with the mind (hypnotherapy, treatment with meditation, prana, and inner energy) (Riskesdas, 2013). Acupressure is a full-blooded or pricking therapy using a massager on a certain point on the body (Setya, 2015).

Acupressure is a complementary action that can reduce blood pressure by giving the sensation of feeling comfortable, aching, arrows, itching, sore when given therapy (Santosa, 2014).

\section{Method}

The design of this research is quasi experimental designs with two group pretest and post-test design approaches. Group 1 was given elderly exercise treatment and in group 2 treatment was given in the form of acupressure. Analysis of the data in this study used a non-parametric statistical test Mann-Whitney at a significant level of $95 \%$. The form of this research design can be described in the following pattern:

\begin{tabular}{|lrr|}
\hline $\mathrm{X}_{1}$ & $\mathrm{O}_{1}$ & $\mathrm{X}_{2}$ \\
\hline $\mathrm{X}_{3}$ & $\mathrm{O}_{2}$ & $\mathrm{X}_{4}$ \\
\hline
\end{tabular}

Information:

X1: Blood pressure before given elderly exercise

X3: Heart blood pressure before being given acupressure

O1: Treatment of 1 elderly exercise

O2: Treatment of 2 acupressure

X2: Results of measurements with elderly gymnastics

X4: Acupressure measurement results

\section{Result and Discussion}

Tabel 1. Bivariate Test Results of Pre and Post Gymnastics Elderly and Acupressure.

\begin{tabular}{|c|c|c|c|}
\hline Test & Treatment & Criteria & $\begin{array}{c}\mathrm{P} \\
\text { value }\end{array}$ \\
\hline Wilcoxon & $\begin{array}{l}\text { Elderly Gymnastics } \\
\text { Systolic before and } \\
\text { after }\end{array}$ & $\mathrm{P}<0.05$ & 0.163 \\
\hline $\begin{array}{l}\text { Paired } \\
\text { t-test }\end{array}$ & $\begin{array}{l}\text { Elderly Gymnastics } \\
\text { Diastolic before and } \\
\text { after }\end{array}$ & $\mathrm{P}<0.05$ & 1.000 \\
\hline $\begin{array}{l}\text { Paired } \\
\text { t-test }\end{array}$ & $\begin{array}{l}\text { Acupressure } \\
\text { Sistolic before and } \\
\text { after }\end{array}$ & $\mathrm{P}<0.05$ & 0.832 \\
\hline $\begin{array}{l}\text { Paired } \\
\text { t-test }\end{array}$ & $\begin{array}{l}\text { Acupressure } \\
\text { Diastolic before and } \\
\text { after }\end{array}$ & $\mathrm{P}<0.05$ & 0.591 \\
\hline
\end{tabular}

Table 1 shows that there is no difference between before and after the elderly and acupressure exercises.

Tabel 2. Bivariate Test Results for Differences in Elderly and Acupressure Gymnastics Pressure.

\begin{tabular}{clccc}
\hline \multicolumn{1}{c}{ Test } & Treatment & $\begin{array}{c}\text { Mean } \\
\text { Control }\end{array}$ & $\begin{array}{c}\text { Mean } \\
\text { Intervensi }\end{array}$ & Result \\
\hline $\begin{array}{l}\text { Independent } \\
\text { t-test }\end{array}$ & $\begin{array}{l}\text { Elderly } \\
\text { gymnastics } \\
\text { and }\end{array}$ & 1.90 & 2.50 & $\begin{array}{c}\text { More effective } \\
\text { intervention } \\
\text { groups }\end{array}$ \\
& & & & groupressure \\
\hline
\end{tabular}

Table 2 shows that acupressure as an intervention group is more effective than elderly exercise as a control group.

From the results of the study stated that the elderly exercise and acupressure did not show an influence on changes in blood pressure before and after the administration of the intervention in the first treatment to the third treatment, this was indicated by sig $>0.05$. This is contrary to the theory that the elderly and acupressure exercises can lower blood pressure because it makes the dilation of blood vessels (vasodilation) and open blood vessels that have not yet opened blood flow and tissue. Besides that, from the results of the mean difference in acupressure and elderly exercise, it was seen that acupressure was more effective in lowering blood pressure than elderly exercise. This is in accordance with the theory that 
acupressure more quickly stimulates nerve waves so that it can launch blood flow and relax spasms of blood vessels.

\section{Conclusion and Suggestion}

Based on the results of research conducted concluded that there was no difference in blood pressure before and after elderly exercise. Furthermore there is no difference in blood pressure before and after acupressure. However, acupressure is more effective in lowering blood pressure in the elderly compared to elderly exercise. Suggestions that can be given in this study are to increase the intensity of exercise and acupressure in lowering blood pressure so that the results are more effective. In addition to increasing the number of respondents and increasing the homogeneity of the sample so that results are more accurate.

\section{Acknowledgements}

Thank you to Poltekkes Kemenkes Semarang for provided fund during this research

\section{References}

Liu X, Xiang Z, Shi X, Schenck H, Yi X, Ni R. (2017). The Risk Factors Of High Blood Pressure Among Young Adults In The Tujia-Nationality Settlement Of China. Biomed Research International. 1-6.

Jateng D. (2015). Profil Kesehatan Jawa Tengah Dinas Provinsi Jawa Tengah.

Mayuni Igao. (2013) Senam Lansia Menurunkan Tekanan Darah Lansia. Populasi.

Kemenkes. Riskesdas. (2013). Badan Penelitian Dan Pengembangan Kesehatan Kementerian Kesehatan RI.

Setya D. (2015) Pengaruh Terapi Akupresur Pada Pasien Hipertensi Di Klinik Synergy Mind Health Surakarta, Kusuma Husada.

Santoso Eb, Susilo Aj, Pranata Ae. (2014). Perbedaan Tingkat Tekanan Darah Sebelum Dan Sesudah Dilakukan Tindakan Akupresur Pada Penderita Hipertensi Lansia Di Pslu Puger Kabupaten Jember. Jurnal Kesehatan Dr Soebandi. 3(1):155. 